\title{
Integrative taxonomy reveals a new species of pacu (Characiformes: Serrasalmidae: Myloplus) from the ๑ Brazilian Amazon
}

Correspondence: Rafaela Priscila Ota rafaelapota@gmail.com

Submitted September 24, 2019

Accepted February 13, 2020 by George Mattox Published April 20, 2020

\author{
๑Rafaela Priscila Ota ${ }^{1},{ }^{\oplus}$ Valéria Nogueira Machado², \\ $\odot$ Marcelo C. Andrade 3 , $\odot$ Rupert A. Collins ${ }^{4}$, $\oplus$ Izeni Pires Farias ${ }^{2}$ \\ and $\odot$ Tomas Hrbek ${ }^{2}$
}

Pacus of the genus Myloplus represent a formidable taxonomic challenge, and particularly so for the case of $M$. asterias and M. rubripinnis, two widespread and common species that harbor considerable morphological diversity. Here we apply DNA barcoding and multiple species discovery methods to find candidate species in this complex group. We report on one well-supported lineage that is also morphologically and ecologically distinct. This lineage represents a new species that can be distinguished from congeners by the presence of dark chromatophores on lateral-line scales, which gives the appearance of a black lateral line. It can be further diagnosed by having 25-29 branched dorsal-fin rays (vs. 18-24), 89-114 perforated scales from the supracleithrum to the end of hypural plate (vs. 56-89), and 98-120 total lateral line scales (vs. 59-97). The new species is widely distributed in the Amazon basin, but seems to have a preference for black- and clearwater habitats. This ecological preference and black lateral line color pattern bears a striking similarity to the recently described silver dollar Metynnis melanogrammus.

Keywords: COI gene, Cryptic species, Myloplus asterias, Myloplus rubripinnis, Neotropical.
Online version ISSN 1982-0224

Print version ISSN 1679-6225

Neotrop. Ichthyol.

vol. 18, no. 1, Maringá 2020

Epub, Apr 17, 2020
1 Programa de Pós-Graduação em Biologia de Água Doce e Pesca Interior, Instituto Nacional de Pesquisas da Amazônia (INPA), Av. André Araújo, 2936, Petrópolis, 69067-375 Manaus, AM, Brazil. rafaelapota@gmail.com

2 Laboratório de Evolução e Genética Animal (LEGAL), Programa de Pós-Graduação em Biodiversidade e Biotecnologia da Amazônia Legal-Rede Bionorte, Departamento de Genética, Universidade Federal do Amazonas (UFAM), 69080-900 Manaus, AM, Brazil. (VNM) valeria.pesca@gmail.com; (IPF) izeni@evoamazon.net; (TH) tomas@evoamazon.net

3 Universidade Federal do Pará, Cidade Universitária Prof. José Silveira Netto, Av. Augusto Corrêa, 1, Guamá, 66075-110 Belém, PA, Brazil. andrademarcosta@gmail.com

4 School of Biological Sciences, University of Bristol, Life Sciences Building, 24 Tyndall Avenue, Bristol, BS8 1TQ, UK. rupertcollins@gmail.com 
Pacus do gênero Myloplus representam um desafio taxonômico formidável, e particularmente o caso de $M$. asterias e $M$. rubripinnis, duas espécies amplamente distribuídas e comuns que abrigam uma considerável diversidade morfológica. Aplicamos aqui a tecnologia do DNA barcoding e múltiplos métodos de descoberta de espécies para encontrar possíveis espécies novas nesse grupo complexo. Registramos uma linhagem bem suportada que também é distinta morfológica e ecologicamente. Essa linhagem representa uma nova espécie que pode ser distinguida das demais congêneres por apresentar cromatóforos escuros nas escamas da linha lateral que conferem uma aparência de linha lateral preta. Ela pode ser adicionalmente diagnosticada por ter 25-29 raios ramificados na nadadeira dorsal (vs. 18-24), 89-114 escamas perfuradas do supracleitro até o final da placa hipural (vs. 56-89) e 98-120 escamas totais na linha lateral (vs. 59-97). A nova espécie é amplamente distribuída na bacia Amazônica, mas aparentemente possui preferência por habitats de água preta e clara. A preferência ecológica e o padrão de colorido escuro da linha lateral consistem em semelhanças impressionantes com o silver dólar recém descrito Metynnis melanogrammus.

Palavras-chave: Espécie críptica, Gene COI, Myloplus asterias, Myloplus rubripinnis, Neotropical.

\section{INTRODUCTION}

Myloplus Gill, 1896 is currently represented by 15 valid species widely distributed in South America, being found in the Amazon, Orinoco, La Plata and São Francisco drainages, as well as the coastal rivers of the Guiana Shield in Brazil, Guyana, French Guiana, Suriname, and Venezuela (Jégu, 2003; Andrade et al., 2016a,b; Andrade et al., 2018, 2019; Nico et al., 2018). The species richness of the genus has been underestimated for decades, as attested by the recent descriptions of four species - M. lucienae Andrade, Ota, Bastos, Jégu, 2016, M. taphorni Andrade, López-Fernández, Liverpool, 2019, M. tumukumak Andrade, Jégu, Gama, 2018, and M. zorroi Andrade, Jégu, Giarrizzo, 2016increasing the species diversity by $25 \%$ since the revalidation of the genus (Jégu et al., 2004).

Jégu et al. (2004) diagnosed the genus Myloplus by the following characters: premaxillary molariform teeth arranged in two rows, spaced by an internal gap among each other; teeth of labial row not in contact at the symphysis; narrow olfactory fossa; long lateral premaxillary process extending beyond the last tooth base; and welldeveloped prepelvic spines. In their study, Jégu et al. (2004) also redescribed M. asterias (Müller, Troschel, 1844), the type species of the genus, and Myloplus rubripinnis (Müller, Troschel, 1844). Both M. asterias and M. rubripinnis were described from Guyana and are morphologically very similar, but diagnosable from one another by the presence of 25-28 dorsal-fin rays and circular-shaped anterior fontanel in $M$. asterias (Jégu et al., 2004: 136, fig. 13b); vs. 25 or fewer dorsal-fin rays, and an oval-shaped fontanel in $M$. rubripinnis (Jégu et al., 2004: 150, fig. 17b). 
Machado et al. (2018) in a taxonomically broad DNA barcoding study of the Serrasalmidae comprising more than 1,000 specimens representing 69 described species and 16 genera, and using four species discovery methods, recovered Myloplus as the serrasalmid genus with the greatest intraspecific lineage diversity. Six of the 12 species included in the study were estimated to comprise multiple lineages, with up to seven lineages solely in $M$. asterias, highlighting the difficulties in the current diagnosis of this species, and the potentially hidden diversity within Myloplus.

The accessibility of molecular techniques to taxonomists has increased the number of species descriptions that include molecular data (e.g., Benine et al., 2009; Melo et al., 2016; Andrade et al., 2017; Escobar et al., 2019). In the "candidate species” framework (Padial et al., 2010), these genetic data can provide initial hypotheses for the existence of new species, and then assist in their subsequent description, if corroborated (e.g., Costa et al., 2014; Escobar et al., 2015, 2019). Here we carried out detailed morphological analysis of the voucher specimens from one of the seven $M$. asterias lineages reported by Machado et al. (2018), and reveal morphological characters that unambiguously diagnose it from remaining congeners. We describe this lineage as a new species of Myloplus, following the diagnosis of the genus by Jégu et al. (2004).

\section{MATERIAL AND METHODS}

Morphological analysis. Counts and measurements follow Jégu et al. (2003). Counts were taken under a stereomicroscope, and measurements with a digital caliper to the nearest $0.1 \mathrm{~mm}$, taken point-to-point on the left side whenever possible. All measurements are presented as percentages of standard length (SL), except for the subunits of head, expressed as percentages of head length (HL). The ventral keel is described as being composed of prepelvic spines (including those anterior to pelvic-fin origin), and postpelvic spines (those posterior to and including the spines near pelvic-fin origin), followed by the number of paired spines around anus.

Osteological features included in the Description section were analyzed in two skeletonized (skel) specimens (INPA 53281), and from two x-rayed specimens (INPA 54474-holotype, and INPA 46320). Dried skeletons were prepared with addition of dermestid beetle larvae and x-ray radiographs taken in Faxitron ${ }^{\circledR}$ specimen radiography system LX-60 (www.faxitron.com) $40 \mathrm{kV}$. Vertebral counts include those of the Weberian apparatus as four elements, and the fused PU1+U1 as a single centrum. Osteological terminology follows Mattox et al. (2014).

Counts are followed by their frequency in parentheses, with an asterisk indicating the count observed in the holotype. In the comparative material list, the number of specimens of each lot is given first, followed by those skeletonized or x-rayed, by tissue voucher number (CTGA), and finally by GenBank accession number in parentheses. Information on sexual dimorphism, including sex and breeding condition of the dissected material was determined according to Vazzoler (1996).

Institutional abbreviations are ANSP, Academy of Natural Sciences, Philadelphia; BMNH, Natural History Museum, London; INPA, Instituto Nacional de Pesquisas da Amazônia, Manaus; MZUSP, Museu de Zoologia da Universidade de São Paulo, São Paulo; NUP, Coleção Ictiológica do Núcleo de Pesquisas em Limnologia, Ictiologia 
e Aquicultura (Nupélia), Maringá; NMW, Naturhistorisches Museum, Zoologische Abteilung, Fische, Vienna; ZUFMS, Coleção Zoológica da Universidade Federal de Mato Grosso do Sul, Campo Grande.

Molecular analysis. For the molecular analyses we combined $377 \mathrm{COI}$ sequences published by Machado et al. (2018), with an additional 29 sequences from newly collected material. As Myloplus is not monophyletic (Thompson et al., 2014), we included representatives of all genera of the "teal" lineage of Thompson et al. (2014) Myloplus, Myleus Müller, Troschel, 1844, Mylesinus Valenciennes, 1850, Ossubtus Jégu, 1992, Tometes Valenciennes, 1850, Utiaritichthys Miranda Ribeiro, 1937, and Acnodon Eigenmann, 1903 - in our analyses. The final dataset contained representatives of 11 of the 15 recognized species of Myloplus: M. arnoldi Ahl, 1936, M. asterias, M. levis (Eigenmann, McAtee, 1907), M. lobatus (Valenciennes, 1850), M. lucienae, M. planquettei Jégu, Keith, Le Bail, 2003, M. rhomboidalis (Cuvier, 1818), M. rubripinnis, M. schomburgkii (Jardine, 1841), M. tiete (Eigenmann, Norris, 1900), and M. zorroi. No tissues or sequences of M. taphorni, M. ternetzi (Norman, 1929), M. tumukumak or M. torquatus (Kner, 1858) were available. The dataset contained sequences from individuals collected from 12 major tributaries of the Amazon basin in Brazil, including: Jari, Negro, Tapajós, Trombetas, Jatapu, Nhamundá, Japurá, Juruá, Javari, Jutaí, Madeira, and Xingu river basins; and also from Tocantins-Araguaia and Paraná-Paraguai systems.

For the newly collected tissue samples, collection, storage, DNA isolation, PCR, sequencing and assembly protocols followed Machado et al. (2018). Briefly, tissue samples from all new specimens were stored in 95\% ethanol and deposited in the CTGA tissue collection of Universidade Federal do Amazonas, Manaus (UFAM), while specimens were fixed in 10\% formalin and deposited in the fish collection of INPA. DNA was extracted using standard salt precipitation protocol (Sambrook, Russel, 2001), amplified and sequenced using primers and PCR protocol reported in Machado et al. (2018). The sequence data were assembled in Geneious Prime v2019.2.1 (https://www. geneious.com) and aligned with the sequences published by Machado et al. (2018) using MAFFT v7.271 (Katoh, Standley, 2013). Species discovery was carried out using four methods-localMinima (spider package v1.5.0; Brown et al., 2012), mPTP v0.2.4 (Kapli et al., 2017), bGMYC v1.0.2 (Reid, Carstens, 2012), and GMYC (splits package v1.0-19; Fujisawa, Barraclough, 2013)—also following Machado et al. (2018). The dataset was first collapsed into unique haplotypes using hapCollapse (https:// github.com/legalLab/protocols-scripts/blob/master/scripts/hapCollapse.R), followed by gene tree estimation using BEAST v1.10.4 (Suchard et al., 2018). Here, the TN93+ substitution model (single partition) as selected by jModeltest v2.1.10 (Darriba et al., 2012) was used, together with a strict molecular clock and a coalescent tree prior. Three independent posterior estimates were made, each of 20 million generations total length, and subsampled every 18,000 generations. This resulted in a combined posterior sample of 3,333 trees, with 3,000 remaining after a burn-in of roughly $10 \%$, as estimated by Tracer v1.7.1 (Rambaut et al., 2018). A maximum clade credibility tree was generated from the posterior tree sample using TreeAnnotator v1.10.4 (https://beast.community/ treeannotator), with common ancestor node heights, and was then used for the species discovery analyses using mPTP, bGMYC, and GMYC. Prior to running mPTP, the consensus chronogram topology was converted to a phylogram using $\mathrm{TN} 93+\Gamma$ branch 
lengths estimated by phangorn v2.5.5 (Schliep, 2011). The localMinima analyses were carried out on the fully uncollapsed dataset using $p$ distances and pairwise deletion of missing data. All species delimitation estimates were single threshold models.

\section{RESULTS}

Myloplus nigrolineatus, new species

urn:1sid:zoobank.org:act:045EB69A-EC87-4D58-AF6D-0E00AF1259BD

(Figs. 1-4; Tab. 1)

Myloplus asterias-Machado et al., 2018: 8 (Brazil, rio Nhamundá, fig. 3d).

Myloplus sp. -Zeinad, Prado, 2012: 148 (Brazil, rio Itapará, tributary of rio Branco, photo).

Myloplus aff. asterias-Morales et al., 2019: 6, 9 (Brazil, Tucuxi lake, rio Purus, Tab. 2, fig. 2, 3 and 4).

Holotype. INPA 54773, 1, x-rayed, 221.9 mm SL, CTGA 15249 (GenBank accession MG752242), Brazil, Amazonas State, ca. 60 km south of Manaus, lago Tracajá, tributary of rio Juma, rio Amazonas basin, 341'15”S 5957’01”W, 22 Nov 2014, V. N. Machado.

Paratypes. All from Brazil. Amazonas State: INPA 54774, 3, x-rayed, 203.2-231.7 mm SL, CTGA 15246 (MG752239), 15247 (MG752240), and 15250 (MG752243), collected with holotype. Rio Negro basin: INPA 925, 6, 182.6-237.7 mm SL, Novo Airão, ilha de Tamaquare, rio Negro, 253'00"S 60³0’59”W, 14 Oct 1979, M. Goulding; INPA 22326, 9, 145.5-197.5 mm SL, Novo Airão, rio Negro, Anavilhanas, $2^{\circ} 43^{\prime} 05^{\prime}$ 'S 6045’16"W, Jan 1981, M. Goulding; INPA 23312, 2, 182.0-199.1 mm SL, São Gabriel da Cachoeira, lago Mabi, 055’49”N 6647’37”W, 22 Feb 2014, V. N. Machado; INPA 52505, 3, 182.3-202.7 mm SL, CTGA 12278 (MG752202), 12329 (MG752209), and 12331 (MG752211), Barcelos, rio Negro nearby Barcelos, 056’56”S 62 55'44”W, 20 Feb 2013, V. N. Machado; INPA 52506, 3, 159.9-193.4 mm SL, CTGA 12323 (MG752203), 12325 (MG752205), and 12327 (MG752207), same data as INPA 52505; INPA 53281, 2, skel., 170.7-180.3 mm SL, Manaus, rio Negro nearby Manaus, ca. $3^{\circ} 08^{\prime} \mathrm{S} 59^{\circ} 54^{\prime} \mathrm{W}, 18$ Apr 2017, local fisherman; INPA 54770, 1, $181.2 \mathrm{~mm}$ SL, Manaus, rio Puduari, Parque Estadual do Rio Negro, 2²3'57”S 61 21'08”W, 21 Apr 2005, F. Mendença, F. Pires \& M. Picasso. Rio Maués-Açu basin: INPA 34810, 2 , 172.5-174.5 SL, Maués, rio Parauari, community Monte Sinai, 4²1’28”S 57³5’54”W, 31 May 2005, R. R. de Oliveira \& W. Pedrosa. Rio Purus basin: INPA 58772, 1, 189.3 mm SL, Manicoré, lago Tapauá, rio Purus, 543’14”S 63¹7’12”W, D. Castanho \& A. G. Bifi. Rio Urubu: INPA 58873, 1, $155.9 \mathrm{~mm} \mathrm{SL}$, Itacoatiara, lago Serpa, tributary of rio Urubu, 3 0 05'11"S 58 30'25”W, 13 Jul 2018, R. G. Amaral da Silva. Mato Grosso, rio Madeira basin: INPA 56750, 1, 104.5 mm SL, CTGA 15231 (MG752238), Aripuanã, confluence of rio Branco and rio Aripuanã, 9 46'41"S 59 23'53"W, 9 Dec 2014, V. N. Machado. Pará, rio Nhamundá: ANSP 207984, 2, 180.0-205.8 mm SL; INPA 46320, 
6, 1 x-rayed, 178.0-198.8 mm SL, CTGA 14469 to 14474 (MG752220 to MG752225), Nhamundá, community Barão, 1 41'27”S 57²5’20”W, 22 Nov 2013, V. N. Machado \& R. A. Collins; INPA 46321, 1, 125.8 mm SL, CTGA 14365 (MG752214), Nhamundá, community Chave, 1 ${ }^{\circ} 40^{\prime 2} 29^{\prime}$ S 57²8’36”W, 25 Nov 2013, V. N. Machado \& R. A. Collins. Rio Tapajós: INPA 23446, 2, 160.0-161.8 mm SL, CTGA 15393 (MG752246) and 15401 (MG752249), Itaituba, 5 37'46”S 57 15'11"W, 10 Oct 2015, V. N. Machado. Rio Tocantins: INPA 57801, 2, 149.3-167.4 mm SL, CTGA 5765 (MG752188) and 5766 (MG752189), Tucuruí, 348'29”S 4940’17”W, 6 Nov 2009, V. N. Machado. Roraima, rio Branco basin: INPA 46279, 4, 172.6-197.1 mm SL, CTGA 12201 (MG752197), 12202 (MG752198), 12204 (MG752199), and 12205 (MG752200), Rorainópolis, left bank of rio Branco, $0^{\circ} 58^{\prime} 08^{\prime}$ "S $61^{\circ}$ 54’02"W, 17 Feb 2013, V. N. Machado; INPA 54772, 1, $179.2 \mathrm{~mm} \mathrm{SL}$, Caracaraí, beach at rio Água Boa do Univini, Serra da Mocidade, $1^{\circ} 11^{\prime} \mathrm{N} 61^{\circ} 41^{\prime} \mathrm{W}, 9$ Apr 2017, D. A. Bastos.

Non-types. Amazonas, rio Juruá basin: INPA 58915, 4, 147.4-164.6 mm SL, CTGA 16865 (MN702903), 16866 (MN702887), 16868 (MN702901), 16869 (MN702902), Carauari, lago Pauapixuna, 449’11"S 6650'54”W, 1 Mar 2018, V. N. Machado. Rio Negro basin: INPA 895, 3, 190.3-218.2 mm SL, Santa Isabel do Rio Negro, rio Maraiuá, ca. $0^{\circ} 14$ 'S $65^{\circ} 10^{\prime} \mathrm{W}, 14$ Oct 1979, M. Goulding; INPA 931, 10, 160.7-208.2 mm SL, Santa Isabel do Rio Negro, igarapé Ibará, ca. 0¹1’S 6555’W, 20 Mar 1980, M. Goulding; INPA 937, 6, 166.7-194.5 mm SL, São Gabriel da Cachoeira, ca. 003'S $68^{\circ} 07^{\prime} \mathrm{W}$, Apr-May 1980, M. Goulding; INPA 22194, 9, 144.1-235.7 mm SL, Barcelos, rio Arirará, close to the confluence with rio Negro, ca. $0^{\circ} 30^{\prime} \mathrm{S} 63^{\circ} 32^{\prime} \mathrm{W}$, Feb 1980, M. Goulding. Rio Uatumã basin: INPA 46058, 1, 119.6 mm SL, Balbina, cachoeira Terceira Queda, rio Pitinga, Amazonas, 107’00”S 59³6’00”W, 26 Sep 1996, V. Garcia. Rio Javari: INPA 58914, 3, 161.3-185.7 mm SL, CTGA 17492 (MN702891), 17493 (MN702892), 17494 (MN702893), Atalaia do Norte, ca. 4²0’S 70¹3’W, 1 Oct 2018, V. N. Machado.

Diagnosis. Myloplus nigrolineatus can be easily diagnosed from all congeners by highly concentrated dark chromatophores on the lateral-line scales, resulting in a markedly, dark pigmentation along the lateral line. Additionally, the new species can be distinguished from $M$. arnoldi, M. lobatus, M. lucienae, M. planquettei, M. rhomboidalis, M. schomburgkii, and M. zorroi by having 25-29 branched dorsal-fin rays (vs. 18-24). It can be distinguished from $M$. ternetzi by the presence of a symphyseal pair of conical teeth posterior to the main row of dentary ( $v s$. absence); and from M. asterias, M. levis, M. rubripinnis, M. taphorni, M. tiete, M. torquatus, and M. tumukumak by having 89-114 lateral line scales from supracleithrum to end of hypural plate (vs. 56-89) and 98-120 total perforated lateral line scales (vs. 59-97).

Description. Morphometric data are presented in Tab. 1. Body laterally compressed, overall aspect of body elliptical, greatest body depth at vertical through dorsal-fin origin. Dorsal profile of head convex from mouth to vertical through anterior nostril, slightly concave to straight from this point to tip of supraoccipital process, and convex from this point to dorsal-fin origin. Dorsal-fin base slightly to moderately convex. Body profile almost straight from dorsal-fin insertion to adipose-fin origin. Adipose-fin base 
gently convex. Head with ventral half of opercle approximately twice as large as dorsal half, with posterior margin surrounded by thin opercle membrane, covering two scales horizontally at point of greatest head length.

Ventral profile of head and body convex. Ventral keel composed by 23(1), 24(3), 25(1), 26(2), 27(10), 28*(7), 29(14), 30(5), or 32(1) prepelvic spines; plus $8(8), 9^{\star}(13)$, 10(14), 11(5), or 12(3) postpelvic spines; followed by 5(1), 6(6), $7^{\star}(13), 8(12), 9(10)$, or 10(1) paired spines around anus. Total spines composing ventral keel 39(2), 40(1), 41(1), $42(2), 43(6), 44^{\star}(2), 45(9), 46(13), 47(2), 48(5)$, or 49(1). Caudal peduncle relatively short, ventral profile slightly concave.

Mouth terminal to slightly upturned. Two rows of molariform premaxillary teeth, $5^{\star}(45)$ teeth in lingual row, and $2^{\star}(45)$ in labial row. First and second tooth in labial row interspaced by gap from teeth of lingual row. Premaxillary teeth 1-3 of lingual row with moderately sharp edges. Dentary with $5^{\star}(10)$ or $6(28)$ molariform teeth gradually decreasing posteriorly in size. Pair of conical symphyseal teeth posterior to main row of teeth, with cutting edge on anterior margin. Maxillary edentulous.

Ascending premaxillary process elongate, similar width from base to distal tip, with distal tip gently pointed, and moderately inclined relative to lateral premaxillary process. Premaxillary lacking interdigitations at symphysis and strongly attached on mesethmoid. Lateral premaxillary process rectangular, with dorsolateral process extending beyond last tooth, with concavity for maxillary insertion. Three replacement teeth trenches on premaxillary. Dentary rectangular, slightly arched with three rounded or oval replacement tooth-trenches, posterior more elongate. Four bony lamellae at symphysis. Anguloarticular well developed and articulated with quadrate by thin cartilage. Retroarticular contacting posteroventral portion of dentary. Coronomeckelian elongate.

Scales cycloid, minute, and numerous. Perforated scales from supracleithrum to hypural-plate end 89(3), 90(7), 91(2), 92(1), 93(7), 94(1), 95(5), 96*(1), 97(1), 98(1), 99(4), 100(4), 101(1), 102(2), 106(1), 107(1), 108(1), 110(1), or 114(1); total perforated scales on lateral line till base of median caudal-fin rays 98(11), 99(5), 100(5), 101(2), 102(3), 103(2), 105(4), 106(1), 107(2), 108*(2), 110(2), 112(3), 113(1), 119(1), or 120(1). Scale rows above lateral line 50(1), 52(6), 53(5), 54(7), 55(8), 56(6), 57^(5), 58(2), 59(2), or 60(3). Scale rows below lateral line 48(3), 49(7), 50(3), 51(3), 52(4), 53(6), 54(2), $55^{\star}(5), 56(3), 57(3), 58(3)$, or 59(2). Circumpeduncular scales 32(1), 33(7), 34(5), 35(7), $36(10), 37^{\star}(7), 38(6), 39(1)$, or 40(1).

Dorsal fin preceded by strong, forward-oriented spine. Dorsal-fin rays ii-iii, 25(13), $26^{\star}(14), 27(12), 28(5)$, or 29(1). Dorsal-fin origin slightly posterior to vertical through pelvic-fin origin, distal margin variable (see Sexual dimorphism). Adipose-fin distal margin round to sub-rectangular. Pectoral-fin rays i, 11(1), 12(2), 13(6), 14(19), 15*(15), or 16(2); distal margin convex, with anterior rays longest. Pelvic-fin rays i, $6^{\star}(33)$ or $7(10)$ with distal margin convex, anterior rays slightly longest, not reaching vertical through anal-fin origin. Anal-fin rays iii-iv, 33(3), 34(7), 35(8), 36*(15), 37(9), or 38(3). Caudal fin forked with both lobes similar in size.

First branchial arch with 26(1), 27(6), 28(6), 29(4), 30*(14), 31(6), 32(4), or 33(1) total gill rakers; upper branch with $12(15), 13^{\star}(12), 14(13)$, or 15(2) rakers; lower branch with $13(1), 14(7), 15(11), 16^{\star}(19), 17(3)$, or 18(1) rakers; $1(43)$ at cartilage between cerato- and epibranchial. Gas bladder two-chambered, total length $41-50 \%$ SL, with 
extrinsic muscle thin and poorly-developed. Anterior chamber smaller, cylindrical, horizontally positioned, with length 15-19\% SL. Posterior chamber larger, somewhat conical, posteriormost region narrower not very contracted, with length 26-32\% SL, curved downward, with long appendix on distal end (2-3\% SL).

Neurocranium massive, deep and triangular in lateral view (Fig. 2A). Mesethmoid short, pointed and triangular anteriorly in dorsal view (Fig. 2B), dorsal profile convex in lateral view. Lateral wings of mesethmoid elongate. Dorsal portion of lateral ethmoid reaching anteroventral surface of frontal, lateral wing elongated, ventrally directed. Vomer excluded from ventral limit of olfactory fossa. Olfactory fossa circular, poorly developed. Nasal narrow, elongate. Parasphenoid long and gently curved ventrally (Fig. $2 \mathrm{~A}$ ), with very reduced ventral keel on anterior portion, ventral aperture arising two thin projections nearly parallel to each other through ventral margins of prootic and basioccipital. Frontal rectangular, relatively short, approximately $30 \%$ of neurocranium length. Epiphyseal bar dividing cranial fontanel; anterior rounded to slightly oval, posterior narrow somewhat triangular, almost closed (Fig. 2B). Neurocranium with moderate concavity at frontal bone (Fig. 2A). Pterosphenoid laminar, laterally articulated to sphenotic. Orbitosphenoid possessing two laterally compressed bony lamellae, anterior upturned, posteroventral process projecting ventrally with interdigitations on ventral margin not reaching parasphenoid (Fig. 2A). Prootic retangular, with anterodorsal circular aperture. Sphenotic with concave ventral margin, with pointed lateral spine for insertion of dilatator operculi. Parietal with dorsal surface sculptured by many grooves, posterior plate gradually narrower. Intercalar diminute, posteroventrally situated. Pterotic triangular with two-pointed downward directed processes. Epoccipital with lateral arm extending towards posterior margins of parietal and pterotic, separating

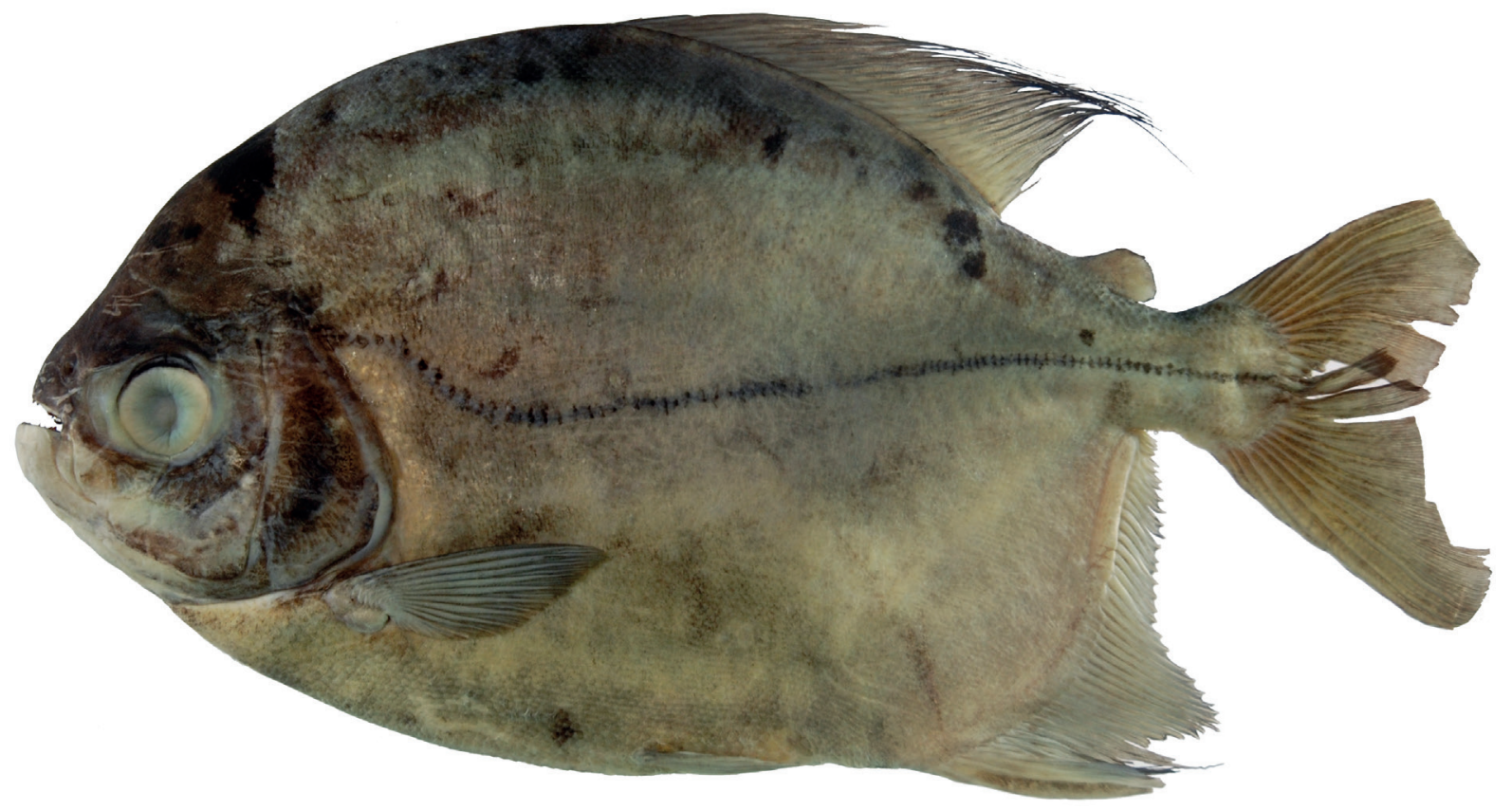

FIGURE 1 I Myloplus nigrolineatus, INPA 54773, holotype, 221.9 mm SL, male, lago Tracajá, tributary of rio Juma, ca. 60 km south of Manaus, Amazonas State, Brazil. 


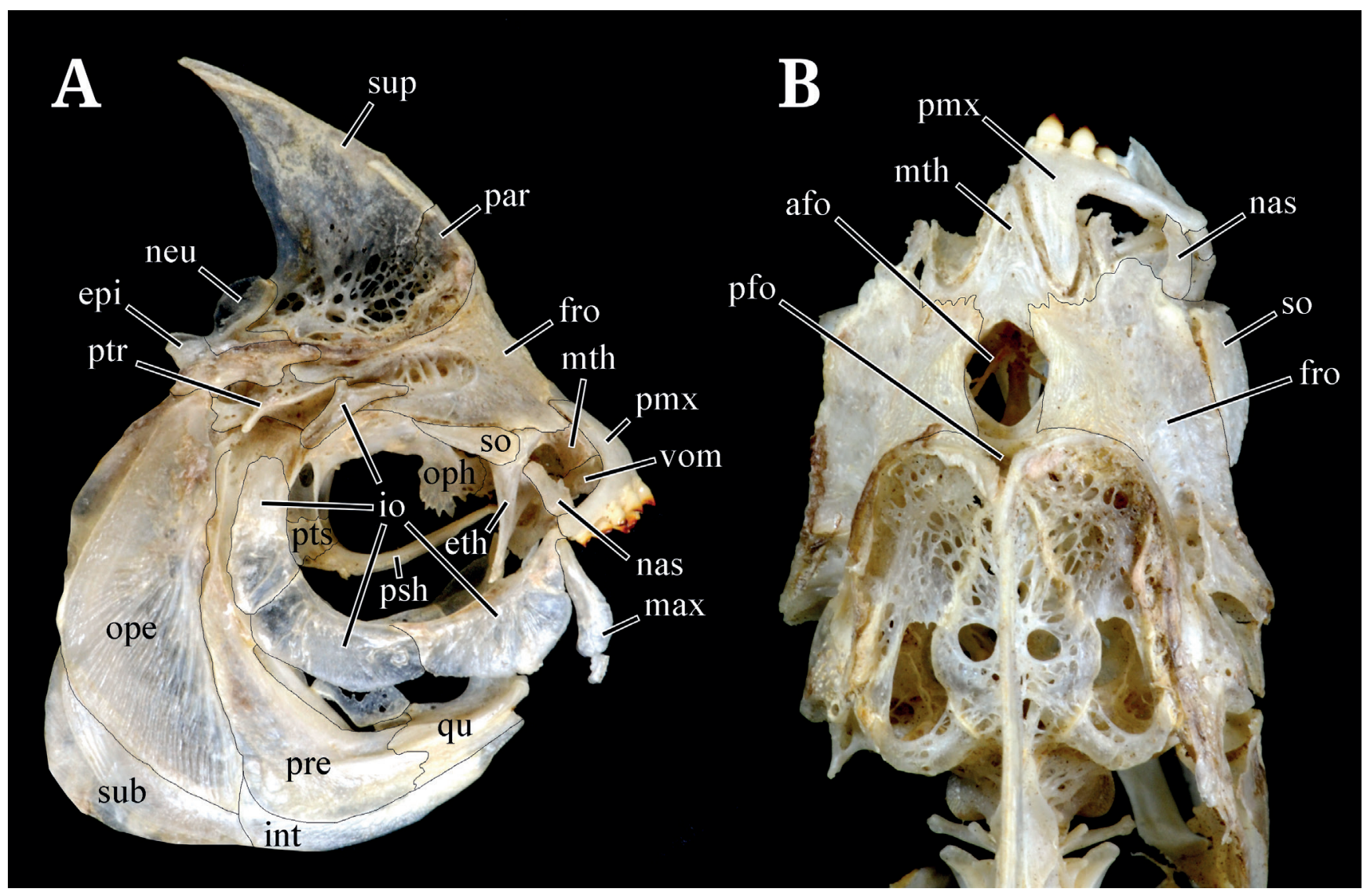

FIGURE 2 I Osteology of the head of Myloplus nigrolineatus, INPA 53281, 180.3 mm SL, Manaus, rio Negro nearby Manaus: A. lateral view;

B. dorsal view. afo, anterior fontanel; epi, epiotic; eth, lateral ethmoid; fro, frontal; int, interopercle; io, infraorbitals; max, maxillary; mth, mesethmoid; nas, nasal; neu, neural; ope, opercle; oph, orbitosphenoid; par, parietal; pfo, posterior fontanel; pmx, premaxillary; pre, preopercle; psh, parasphenoid; ptr, pterotic; pts, pterosphenoid; qu, quadrate; so, supraorbital; sub, subopercle; sup, supraoccipital; vom, vomer.

posttemporal fossa into dorsal and ventral portions. Basioccipital forming entire ventral surface of saccular capsule. Exoccipital with large lagenar capsule. Supraoccipital spine long, well-developed, dorsal profile convex (Fig. 2A).

Infraorbital series well developed. Antorbital robust, with base larger than tip. Six infraorbitals forming semi-circle, leaving a small naked area on cheeks, not covering lateral surface of vertical arm of preopercle. Infraorbital 6 with "Y" shaped laterossensory channel. Supraorbital somewhat oval and narrow with slightly convex anteroventral margin, not contacting infraorbital 6. Orbital region overall wide (Fig. 2A).

Total vertebrae $38(3)$ or $39^{\star}(1)$. Abdominal vertebrae $14(2)$ or $15^{\star}(2)$. Caudal vertebrae $20^{\star}(4)$. Vertebrae between last dorsal-fin pterygiophore and first anal-fin pterygiophore $6(2)$ or $7^{\star}(2)$. Supraneurals $5^{\star}(2)$ or $6(2)$.

Color in alcohol. Ground coloration gray to pale-yellow, head and body darker dorsally. Lateral line scales with melanophores forming dark stripe along flanks 
TABLE 1 I Morphometric data of Myloplus nigrolineatus, new species. Range including the holotype; $\mathbf{N}=$ number of specimens, $\mathbf{S D}=\mathbf{s t a n d a r d}$ deviation.

\begin{tabular}{|c|c|c|c|c|c|}
\hline & Holotype & $\mathbf{N}$ & Range & Mean & SD \\
\hline Standard length (mm) & 221.9 & 44 & $145.7-237.7$ & - & - \\
\hline \multicolumn{6}{|c|}{ Percents of standard length } \\
\hline Body depth & 63.8 & 44 & $58.7-71.0$ & 64.9 & 3.32 \\
\hline Head length & 29.9 & 44 & $26.0-32.0$ & 28.7 & 1.32 \\
\hline Supraoccipital process & 31.7 & 44 & $26.3-33.2$ & 30.1 & 1.68 \\
\hline Predorsal length & 57.6 & 44 & $53.8-58.9$ & 56.7 & 1.36 \\
\hline Dorsal-fin base length & 37.1 & 44 & $33.4-40.1$ & 36.7 & 1.35 \\
\hline Interdorsal length & 7.4 & 44 & $5.8-9.5$ & 7.5 & 0.83 \\
\hline Adipose-fin base length & 4.2 & 44 & $3.7-5.7$ & 4.4 & 0.43 \\
\hline Caudal-peduncle depth & 9.7 & 44 & $8.4-10.7$ & 9.6 & 0.47 \\
\hline Anal-fin base length & 34.2 & 44 & $29.6-37.8$ & 34.1 & 1.91 \\
\hline Preanal length & 79.2 & 44 & $75.0-90.2$ & 78.9 & 2.33 \\
\hline Prepelvic length & 59.5 & 43 & $57.3-63.0$ & 60.0 & 1.54 \\
\hline Prepectoral length & 31.9 & 44 & $28.2-32.8$ & 30.5 & 1.10 \\
\hline Pelvic-anal distance & 22.6 & 43 & $18.6-23.5$ & 21.4 & 1.33 \\
\hline Pelvic-pectoral distance & 28.4 & 43 & $26.8-34.5$ & 30.6 & 1.76 \\
\hline Width of peduncle & 6.0 & 44 & $4.1-6.2$ & 5.1 & 0.57 \\
\hline Pectoral-fin length & 22.6 & 44 & $21.3-25.2$ & 23.2 & 0.94 \\
\hline Pelvic-fin length & 13.6 & 42 & $11.3-14.9$ & 13.5 & 0.87 \\
\hline First anal-fin lobe length & 18.0 & 42 & $13.0-41.7$ & 25.4 & 9.02 \\
\hline Second anal-fin lobe length & 13.6 & 24 & $10.9-17.8$ & 13.7 & 1.89 \\
\hline Dorsal-fin length & 19.6 & 41 & $16.6-29.7$ & 21.9 & 2.82 \\
\hline Dorsal- to anal-fin origin & 67.5 & 44 & $59.7-73.8$ & 67.8 & 3.48 \\
\hline Dorsal-fin end to anal-fin origin & 47.0 & 44 & $43.1-52.8$ & 47.9 & 2.59 \\
\hline Dorsal- to anal-fin end & 21.2 & 44 & $17.3-23.9$ & 20.5 & 1.29 \\
\hline \multicolumn{6}{|c|}{ Percents of head length } \\
\hline Snout length & 25.6 & 44 & $23.5-32.2$ & 27.6 & 2.16 \\
\hline Interorbital width & 51.8 & 44 & $47.1-57.8$ & 52.4 & 2.16 \\
\hline Width head & 58.1 & 43 & $52.3-65.5$ & 59.4 & 2.56 \\
\hline Postorbital distance & 38.7 & 44 & $32.0-41.8$ & 36.7 & 2.28 \\
\hline Fourth infraorbital width & 12.0 & 44 & $9.8-14.7$ & 11.9 & 1.01 \\
\hline Eye vertical diameter & 28.9 & 44 & $27.6-35.3$ & 30.7 & 1.79 \\
\hline Mouth length & 13.1 & 44 & $10.5-16.6$ & 13.4 & 1.37 \\
\hline Third infraorbital width & 11.7 & 44 & $9.7-14.8$ & 12.1 & 1.05 \\
\hline Cheek gap width & 10.8 & 44 & 7.6-14.9 & 10.7 & 1.49 \\
\hline Mouth width & 33.3 & 44 & $30.8-39.6$ & 34.0 & 1.86 \\
\hline
\end{tabular}



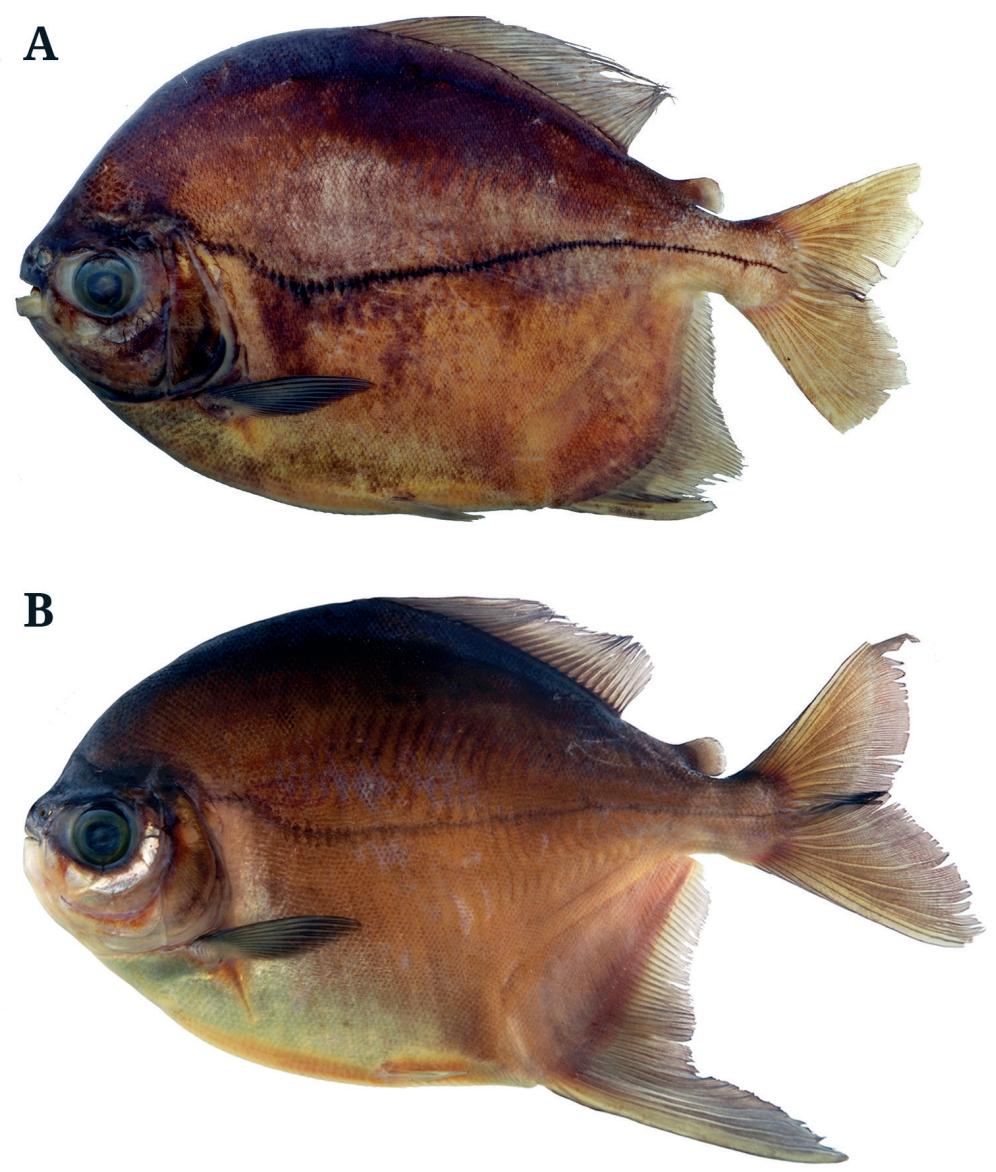

FIGURE 3 I Myloplus nigrolineatus, paratypes, INPA 23312, lago Mabi, São Gabriel da Cachoeira, Amazonas State, Brazil. A. $199.1 \mathrm{~mm}$ SL, male; B. 182.0 mm SL, female.

(Figs. 1, 3); melanophores vertically elongate, similar to stitches (Fig. 4F). Posterior half of scales well-pigmented, anterior half pale. Males with concentration of small dark spots, forming irregular blotches over the body, most dispersed above the lateral line. Light blotches scattered on flanks, predominantly concentrated above lateral line (Figs. 4E, F). Mandibular and gular regions, first four infraorbitals, and cheek gap light brown. Eye with broad dark transversal bar crossing pupil (not discernible in specimens retained for a long period in formalin) (Fig. 4). Dorsal, anal, pelvic and caudal fins overall somewhat hyaline, becoming darker towards fin margins. Pectoral fin light to dark brown. Caudal fin with dark and diffuse distal band.

Color in life. Overall body coloration varying from silvery to plumbeus, with orange blotches scattered on flanks. Dorsal profile of head and inferior half of opercle with high concentration of melanophores. Fins uniformly hyaline or light yellow with scattered dark chromatophores along interradial membranes. Males during breeding period with anterior lobe of anal fin orange to intense red; with irregular-shaped orange to blood-red 
blotch on posterior half of head to supracleithrum region, situated in opercular area, and near pectoral-fin origin. Males during breeding period also possessing dark, irregularly shaped and distributed blotches, more concentrated along dorsal half of flanks (Figs. $4 \mathrm{E}, \mathrm{F})$. Females during breeding period with orange and dark gray irregularly shaped blotches scattered on flanks (Fig. 4B).

Sexual dimorphism. Myloplus nigrolineatus presents the typical sexual dimorphism pattern of other Myloplus species, with males possessing an additional anal-fin lobe centered on 14th or 15th branched ray (Figs. 3A; 4C-F), the presence of stiff hooks
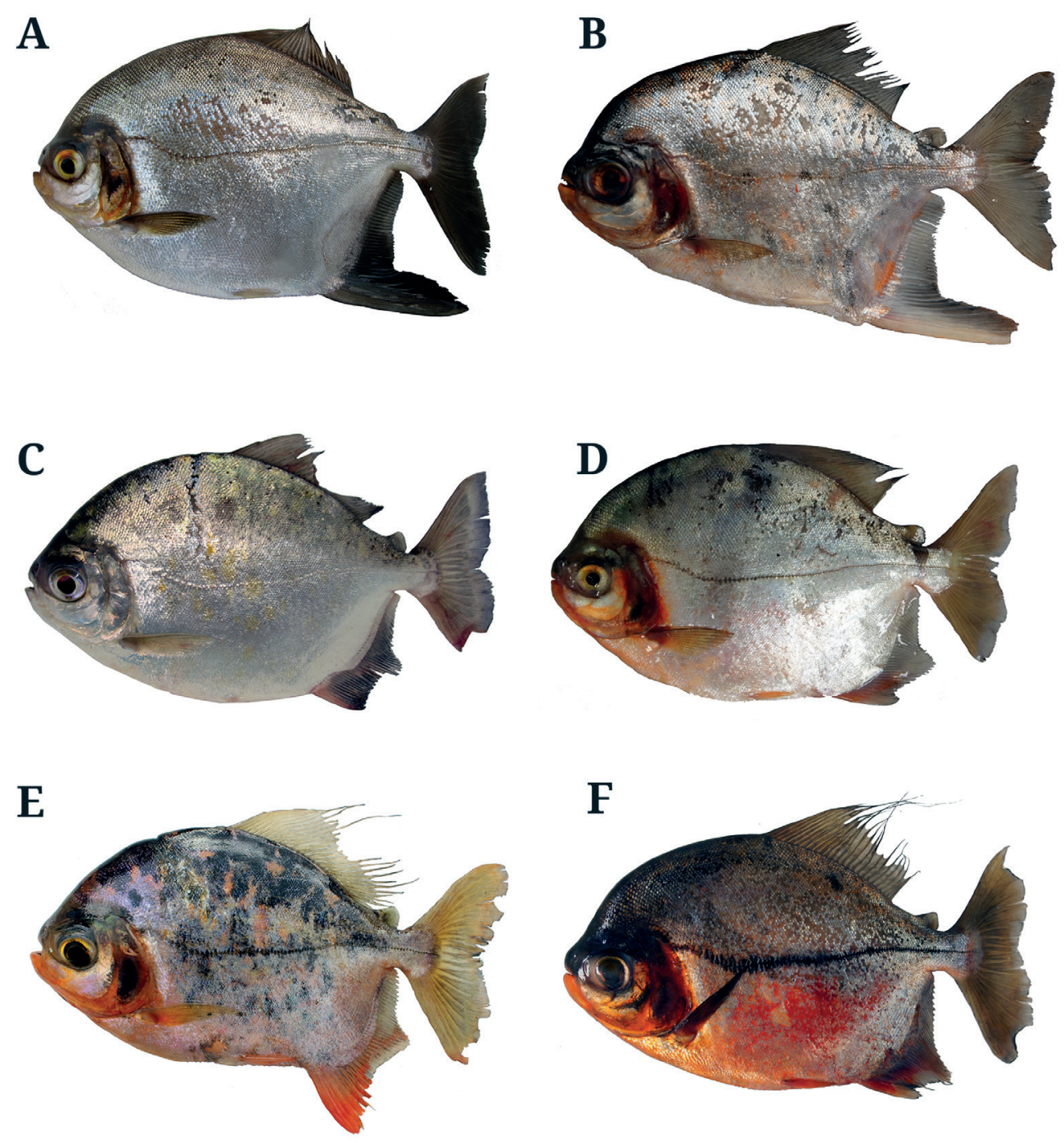

FIGURE 4 I Freshly collected Myloplus nigrolineatus with different color patterns. A. INPA 23312, 182.0 mm SL, female, lago Mabi, São Gabriel da Cachoeira, Amazonas; B. INPA 53281, 170.7-180.3 mm SL, female, rio Negro nearby Manaus, Amazonas; C. INPA 23446, 160.0 mm SL, male, tissue voucher CTGA 15401, Tapajós Itaituba, Pará; D. INPA 46279, 172.3 mm SL, male, tissue voucher CTGA 12201 (GenBank accession MG752197), rio Branco, boundary between Caracaraí and Rorainópolis, Roraima; E. INPA 58772, 189.3 mm SL, male, rio Purus, Tapauá, Amazonas; F. INPA 52505, 186.4 mm SL, male, tissue voucher CTGA 12329 (MG752209), rio Negro nearby Barcelos, Amazonas. 
laterally curved on distal-most lepidotrichia segment of anal-fin branched rays, and by the presence of ossified protuberances on anal-fin branched rays forming additional lobe (absent in females). Male specimens additionally present thin, long filaments extending branched dorsal-fin rays (absent in females; Figs. 4E, F), and display darker background coloration and more intense colors (Figs. 3, 4), with scattered dark and orange blotches more conspicuous than in females (see Color in life). Females have very rigid unbranched anal-fin rays, with first eight to ten rays extremely elongate forming a falcate margin (Figs. 3B; 4A, B). Representatives of Myloplus nigrolineatus in the breeding season show remarkable coloration with intense grayish-orange to blackish-red colors (Figs. 4E, F), while in the non-breeding season these colors are faint (Figs. 4B, C). Dissected females collected in October (INPA 895) and April (INPA 931 and INPA 937) had ripe gonads.

Geographical distribution. Myloplus nigrolineatus is widespread in the Amazon basin, occurring in the Negro, Branco, Nhamundá, Purus, Madeira, Tapajós, Tocantins, and Uatumã rivers (Fig. 5). In whitewater rivers with high sediment loads such as the Madeira, Branco, and Purus, Myloplus nigrolineatus was only captured in tributaries with black- or clearwater (see Ecological notes).

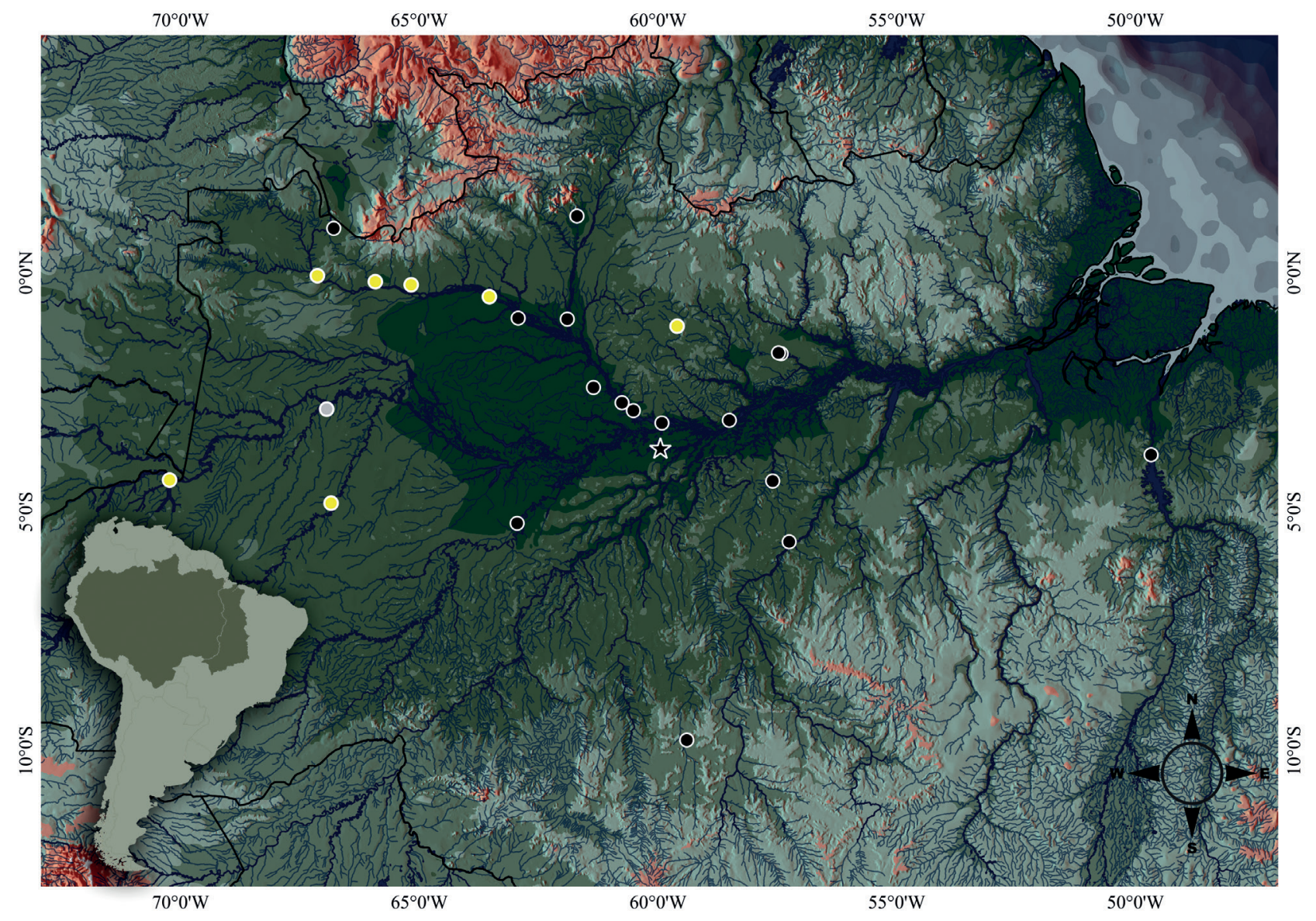

FIGURE 5 I Map of northern South America, showing the distribution of Myloplus nigrolineatus. Black star represent the type locality, black circles the paratypes, yellow the non-types localities, and the gray represents the locality of exemplars used exclusively in the molecular analyses (without voucher in museums). 
Ecological notes. The species inhabits slow-flowing habitats such as backwaters and lakes, feeding mainly on aquatic and terrestrial plants (Goulding, 1980). Of the collection localities, the Aripuanã, rio Água Boa do Univini (rio Branco), Nhamundá, Tapajós, Tocantins, and Uatumã rivers are clearwater rivers chemically characterized by a low concentration of suspended sediments, dissolved minerals and humic compounds (Crampton, 2011), while the rio Negro basin, rio Jutaí, Pauapixuna lake (rio Juruá), Tapauá lake (rio Purus), Serpa lake (rio Amazonas), and rio Maués-Açu are extremely acidic oligotrophic blackwaters (Sioli, 1984; Goulding et al., 1988). The Tracajá lake (holotype locality) is also a blackwater system that has its headwaters in the PurusMadeira interfluvium and like other blackwater rivers, is of low sediment load and low $\mathrm{pH}$. These blackwater environments are inhospitable to certain species of fish (Wallace, 1889; Roberts, 1972; Goulding et al., 1988; Araújo-Lima, Goulding, 1997; Saint-Paul et al., 2000; Crampton, 2011; Lima, Ribeiro, 2011).

Etymology. The epithet nigrolineatus, from the Latin nigro meaning black, and lineatus meaning lined, an allusion to the black, pigmented lateral line. An adjective.

Conservation status. Myloplus nigrolineatus is a common and naturally abundant species, widely distributed within black- and clearwater Amazonian rivers in Brazil. As no specific threats were detected, $M$. nigrolineatus can be tentatively categorized as Least Concern (LC) according to the International Union for Conservation of Nature (IUCN) categories and criteria (IUCN Standards and Petitions Subcommittee, 2017).

Molecular results: The 29 COI barcode sequences generated in this study were deposited in GenBank under the accession codes MN702885-MN702913. Combined with the 377 sequences from Machado et al. (2018) the alignment comprised 406 individuals from 32 morphologically assigned species (https://github.com/legalLab/ publications). After alignment and trimming, the matrix was $621 \mathrm{bp}$ with a median sequence length of $621 \mathrm{bp}$ of non-gap characters ( $\min .=477 \mathrm{bp}$; mean $=605 \mathrm{bp}$ ), and comprised 161 unique haplotypes. Myloplus nigrolineatus was represented by 68 sequences (20 unique haplotypes) from 18 unique sampling localities.

The four species discovery methods partitioned the total dataset into between 39 (localMinima) and 48 (GMYC) lineages (mPTP $=40$; bGMYC = 44; Fig. 6). In Myloplus there were between 25 (localMinima) and 29 (GMYC) lineages ( $\mathrm{mPTP}=26$; bGMYC = 28; Fig. 6). All four methods recovered M. nigrolineatus as a distinct lineage with GMYC partitioning the species into two further groups. Myloplus nigrolineatus had a Bayesian posterior probability of monophyly of 1 in the maximum clade credibility consensus tree, and was found as sister taxon to a lineage of Myloplus from the Tapajós River (posterior probability 0.53 ). Mean genetic distance to the closest non-conspecific of Myloplus nigrolineatus was $2.1 \%$ uncorrected $p$ distance $(\min .=1.8 \%$; $\max .=2.4 \%)$, and $2.5 \% \operatorname{TrN}+\Gamma$ corrected distance $(\min .=2.1 \% ; \max .=3.1 \%)$.

Remarks. Myloplus asterias is the most similar looking congener of M. nigrolineatus, sharing with the new species the general body shape and an elevated number of branched dorsal-fin rays (25-29). However, both species can be diagnosed by the number of total lateral line scales (98-120 in M. nigrolineatus vs. 79-97 in M. asterias). Myletes ellipticus 
FIGURE 6 I Chronogram (maximum clade credibility consensus of 3,000 post burn-in posterior trees) of Myloplus and related genera constructed in BEAST using DNA barcode sequence data. Comprises 161 unique haplotypes (total 406 sequences), with the number of haplotypes represented by each tip in parentheses, followed by the drainages where these haplotypes were recovered. Species discovery congruence for four methods (localMinima, mPTP, bGMYC and GMYC) is presented in colored columns. Branch support (Bayesian posterior probability) of $\geq 95 \%$ is shown with an orange node label. Myloplus nigrolineatus is highlighted with a green box.

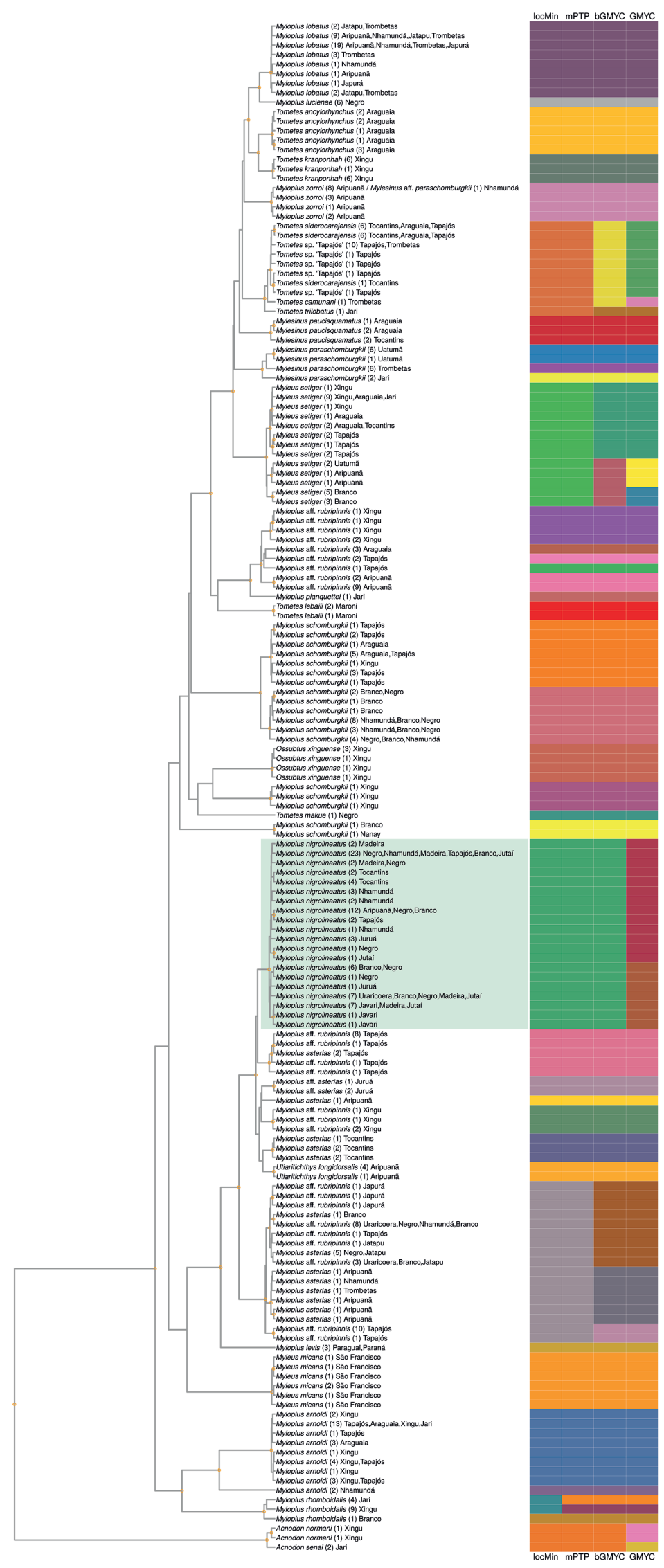


Günther, 1864, Myleus gurupyensis Steindachner, 1911, Myloplus schulzei Ahl, 1938, and Tometes maculatus Amaral Campos, 1944 were considered by Jégu (2003) junior synonyms of Myloplus asterias. Later, Jégu et al. (2004) redescribed Myloplus asterias, and designated its lectotype (ZMB 23686) and paralectotypes (ZMB 3636, 3637, and BMNH 1971.5.10.61, Fig. 7) from Guyana, Essequibo River. Through our analyses of the type material of all these species, we could confirm the number of total lateral line scales (8788 in M. asterias, 91 in Myletes ellipticus, 90 in Myleus gurupyensis, 92 in Myloplus schulzei, and 79 in Tometes maculatus) being lower than that of M. nigrolineatus. Those counts fit in the range of dorsal-fin rays of Myloplus asterias as defined herein, corroborating their synonymy as proposed by Jégu (2003), and, therefore, not representing available names for Myloplus nigrolineatus.

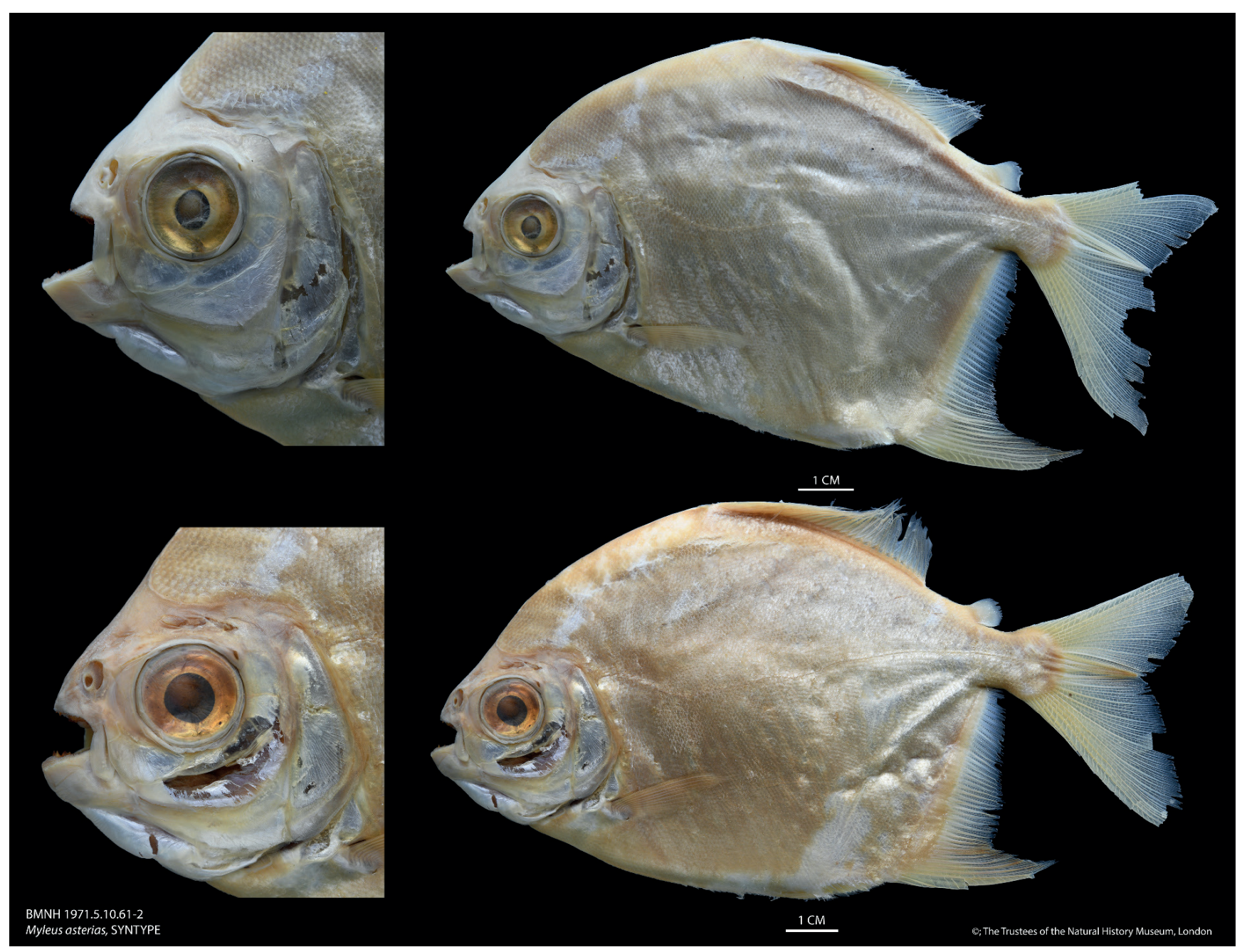

FIGURE 7 I Myleus asterias, paralectotypes, BMNH 1971.5.10.61-2, Essequibo River, Guyana. Photo: Kevin Webb. https://data.nhm.ac.uk/ object/7b7ff23f-df96-47e2-8f6b-dcf25ca45984/1572393600000 


\section{DISCUSSION}

The primary diagnostic feature of Myloplus nigrolineatus, its dark pigmented lateral line, is also shared with another serrasalmid, Metynnis melanogrammus Ota, Rapp PyDaniel \& Jégu, 2016. However, unlike Metynnis melanogrammus, the new species described herein presents variation in the degree of intensity of melanin concentration along the lateral line (Fig. 4), with specimens from the Branco and Tapajós rivers presenting a lateral line with very few melanophores (Figs. 4A-D). Another feature shared between Myloplus nigrolineatus and Metynnis melanogrammus is that both species are widely distributed in black- and clearwater environments of the Amazon basin. Few fish species have such broad spatial distributions extending across multiple Amazonian river basins, but at the same time being restricted to a narrow range of ecological conditions (e.g., Metynnis melanogrammus). Such a pattern may indicate the extreme hydrogeographic dynamism of the whitewater rivers that isolated widespread populations (Ruokolainen et al., 2018), as well as potentially strong intrinsic dispersal ability. Based on data presented here and in Ota et al. (2016), Myloplus nigrolineatus and Metynnis melanogrammus appear to have a contemporary ecological preference for habitats with low $\mathrm{pH}$ and low concentration of suspended sediments and dissolved minerals, with sediment-loaded waters acting as ecological barrier to contemporary dispersal and survival of these black- and clearwater species. However, inferences into the past are unclear at this moment. Studies on fishes with similar distributions spanning such barriers have suggested periods of reduced precipitation and riverine sediment load in the late Pleistocene that may have permitted historical dispersal (Collins et al., 2018). Furthermore, Ruokolainen et al. (2019) suggested that river capture events rearranged the river network in central Amazonia during the late Pleistocene and Holocene, with evidences of paleochannels connecting different rivers, such as from the Juruá to the Jutaí rivers. Future studies are necessary to investigate this distribution pattern, and to test if the black lateral line is related to this ecological preference.

Besides the elevated concentration of melanophores in the lateral line, M. nigrolineatus possesses a combination of diagnostic features to distinguish it from other Myloplus. The new species possesses 25-29 branched dorsal-fin rays ( $v$ s. fewer than 24 in M. arnoldi, $M$. lobatus, M. lucienae, M. planquettei, M. rhomboidalis, M. schomburgkii, and M. zorroi), but compared to M. rubripinnis, M. taphorni, and M. tumukumak (23-25), M. levis (23-27), and $M$. asterias (25-28) this character is not useful to seperate the new species from these latter species. However, despite the overlap of this meristic with M. rubripinnis, M. taphorni, M. tumukumak, M. levis, and M. asterias, M. nigrolineatus has the greatest number of perforated scales from supracleithrum to end of hypural plate (89-114 vs. fewer than 89) and of total lateral line scales among all congeners (98-120vs. fewer than 98).

The DNA barcode data analysed recovered Myloplus nigrolineatus as sister taxon to a lineage of Myloplus from the Tapajós River (Fig. 6), although with low posterior probability. In Machado et al. (2018) this clade was identified as Myloplus rubripinnis. However, Andrade et al. (2018) restricted M. rubripinnis to the Guiana Shield, including the drainages of the Essequibo and Maroni rivers in Guyana and Suriname, the Oyapock River separating French Guiana and Brazil, and the Araguari and Jari rivers in Brazil. Thus, the new species is not sympatric with M. rubripinnis, and its possible sister taxon 
in the Tapajós may represent a new species that needs further investigation. We refer to this taxon here as $M$. aff. rubripinnis because it has 23-25 branched dorsal-fin rays, 80-89 total lateral line scales, and an oval anterior fontanel ( $v s$. a circular anterior fontanel, Fig. 2b). A circular anterior fontanel has only been reported in $M$. asterias, by Jégu et al. (2004: 136, fig. 13b), who proposed the character as a diagnostic feature of that species. However, the specimen illustrated by Jégu et al. (2004) was from the Uatumã River basin, where $M$. asterias and $M$. nigrolineatus are sympatric, and we were not yet able to confirm this character state in the type material of $M$. asterias.

We found that DNA barcodes were highly effective in highlighting and partitioning unrecognized diversity of lineages. This is especially the case within the genus Myloplus, and serrasalmids more generally, where high taxonomic diversity is combined with body shape and color pattern changes during ontogeny and as a result of sexual dimorphism, make them a difficult taxonomic challenge. DNA barcodes can triage large collections and provide starting points for further investigation with more focused methods. Machado et al. (2018) estimated that the epithets M. asterias and M. rubripinnis contained between 11 and 13 COI lineages, while the analysis presented here estimated between 12 and 15 (including $M$. nigrolineatus). Therefore, Myloplus remains a priority for taxonomic revision, and we strongly recommend the use of integrative taxonomic techniques in future studies.

Comparative material examined: Those given in Andrade et al. (2016a,b, 2018) with addition of: Brazil: Myleus gurupyensis: NMW 10589, 175.0 mm SL, syntype. Myloplus arnoldi: INPA 45784, 4, 103.3-112.1 mm SL. Myloplus asterias: INPA 26871, 1, 156.0 mm SL; INPA 39331, 1, 171.9 mm SL. Myloplus levis: NUP 13636, 4, 115.8147.0 mm SL; ZUFMS 4484, 2, 117.8-107.4 mm SL. Myloplus lobatus: INPA 53725, $208.2 \mathrm{~mm}$ SL. Myloplus lucienae: INPA 54771, 1, $167.6 \mathrm{~mm}$ SL. Myloplus rhomboidalis: INPA 40276, 2, 60.8-100.4 mm SL. Myloplus rubripinnis: INPA 4549, 2, 156.0-164.2 mm SL; INPA 53087, 2, 141.5-148.2 mm SL. Myloplus schomburgki: INPA 30716, 1, 143.6 mm SL. Myloplus tiete: INPA 53243, 1, 43.7 mm SL; ZUFMS 3703, 1, 122 mm SL. Myloplus torquatus: INPA 767, $148.1 \mathrm{~mm}$ SL; INPA 20013, 2, 68.2-90.1 mm SL; INPA 36702, 1, $77.5 \mathrm{~mm}$ SL. Myloplus zorroi: INPA 50880, holotype, 1, $326.2 \mathrm{~mm}$ SL. Tomete maculatus: MZUSP 3356, holotype, $168.3 \mathrm{~mm}$ SL. Myloplus planquettei: French Guiana: INPA 2260, 90.9 mm SL. Myloplus ternetzi: INPA 3037, 2, 77.7-84.0 mm SL.

\section{ACKNOWLEDGMENTS}

This study was supported by the Conselho Nacional de Desenvolvimento Científico e Tecnológico (CNPq)/CT-Amazonia (575603/2008-9), Fundação de Amparo a Pesquisa do Estado do Amazonas (FAPEAM)/PRONEX, FAPEAM/SISBIOTA, and CNPq/SISBIOTA-BioPHAM (563348/2010) to IPF. We especially thank Marina Loeb (MZUSP) for helping with the holotype of Tometes maculatus, Carla S. Pavanelli (NUP) for museum and technical support, Renildo R. de Oliveira and Victória D. P. Silva (INPA) for providing pictures of the skeleton used in Fig. 2, and Kevin Webb, Nemo Martin and James Maclaine (NHM London) for Fig. 7. We also thank comments and corrections made by André L. Netto-Ferreira (UFRGS) and an anonymous reviewer 
that greatly improved the quality of the manuscript. RPO is funded by Coordenação de Aperfeiçoamento de Pessoal de Nível Superior (CAPES grant \#12002011001P7). MCA is funded by Postdoctoral National Program of the Aquatic Ecology and Fishery Program of Federal University of Pará (PPGEAP/PNPD/CAPES grant \# 2017-6). IPF and $\mathrm{TH}$ received productivity grants from $\mathrm{CNPq}$.

\section{REFERENCES}

- Andrade MC, Jégu M, Gama CS. A new species of Myloplus Gill (Characiformes, Serrasalmidae) from the Tumucumaque Mountain Range, Brazil and French Guiana, with comments on M. rubripinnis. Zootaxa. 2018; 4403(1):111-22. https://doi. org/10.11646/zootaxa.4403.1.6

- Andrade MC, Jégu M, Giarrizzo, T. A new large species of Myloplus (Characiformes, Serrasalmidae) from the rio Madeira basin, Brazil. Zookeys. 2016a; 571:153-67. https:// doi.org/10.3897/zookeys.571.5983

- Andrade MC, López-Fernandes H, Liverpool EA. New Myloplus from Essequibo River basin, Guyana, with discussion on the taxonomic status of Myleus pacu (Characiformes: Serrasalmidae). Neotrop Ichthyol. 2019; 17(4): e190026. https://doi. org.10.1590/1982-0224-20190026

- Andrade MC, Machado VN, Jégu M, Farias IP, Giarrizzo, T. A new species of Tometes Valenciennes 1850 (Characiformes: Serrasalmidae) from Tocantins-Araguaia river basin based on integrative analysis of molecular and morphological data. PloS One. 2017; 12(4):e0170053. https://doi.org/10.1371/ journal.pone.0170053

- Andrade MC, Ota RP, Bastos DA, Jégu M. A new large Myloplus Gill 1896 from rio Negro basin, Brazilian Amazon (Characiformes: Serrasalmidae). Zootaxa. 2016b; 4205(6):571-80. https://doi. org/10.11646/zootaxa.4205.6.5

- Araújo-Lima C, Goulding M. So fruitful a fish: Ecology, conservation and aquaculture of the Amazon's tambaqui. New York: Columbia University Press; 1997.
- Benine RC, Mariguela TC, Oliveira C. New species of Moenkhausia Eigenmann, 1903 (Characiformes: Characidae) with comments on the Moenkhausia oligolepis species complex. Neotrop Ichthyol. 2009; 7(2):161-68. https://doi.org/10.1590/S167962252009000200005

- Brown SDJ, Collins RA, Boyer S, Lefort MC, Malumbres-Olarte J, Vink CJ, Cruickshank RH. SPIDER: an R package for the analysis of species identity and evolution, with particular reference to DNA barcoding. Mol Ecol Resour. 2012; 12:562-65. https://doi.org/10.1111/j.17550998.2011.03108.x

- Collins RC, Bifi AG, de Oliveira RR, Ribeiro ED, Lujan NK, Rapp Py-Daniel LH, Hrbek T. Biogeography and species delimitation of the rheophilic suckermouth catfish genus Pseudolithoxus (Siluriformes: Loricariidae), with the description of a new species from the Brazilian Amazon. Syst Biodivers. 2018; 16(6):538-50. https://doi.or g/10.1080/14772000.2018.1468362

- Costa WJEM, Amorin PE, Aranha GN. Species limits and DNA barcodes in Nematolebias, a genus of seasonal killifishes threatened with extinction from the Atlantic Forest of south-eastern Brazil, with description of a new species (Teleostei: Rivulidae). Ichthyol Explor Freshw. 2014; 24(3):225-36.

- Crampton WGR. An ecological perspective on diversity and distributions. In: Albert JS, Reis RE, editors. Historical biogeography of Neotropical freshwater fishes. Los Angeles: University of California Press; 2011. p.165-89.

- Darriba D, Taboada GL, Doallo R, Posada D. jModelTest 2: more models, new heuristics and parallel computing. Nat Methods. 2012; 9:772. https://doi. org/10.1038/nmeth.2109 
- Escobar MD, Andrade-López J, Farias IP, Hrbek T. Delimiting evolutionarily significant units of the fish, Piaractus brachypomus (Characiformes: Serrasalmidae), from the Orinoco and Amazon River Basins with insight on routes of historical connectivity. J Hered. 2015; 106:428-38. https://doi.org/10.1093/ jhered/esv047

- Escobar L. MD, Ota RP, Machado-Allison A, Andrade-López J, Farias IP, Hrbek T. A new species of Piaractus (Characiformes: Serrasalmidae) from the Orinoco Basin with a redescription of Piaractus brachypomus. J Fish Biol. 2019; 1-17. https://doi.org/10.1111/jfb.13990

- Fujisawa T, Barraclough TG. Delimiting species using single-locus data and the Generalized Mixed Yule Coalescent approach: a revised method and evaluation on simulated data sets. Syst Biol. 2013; 62(5):707-24. https://doi. org/10.1093/sysbio/syt033

- Goulding M. The fishes and the forest: explorations in Amazonian natural history. Berkeley: University of California Press; 1980.

- Goulding M, Carvalho ML, Ferreira EG. Río Negro: rich life in poor waters: Amazonian diversity and foodchain ecology as seen through fish communities. The Hague: SPB Academic Publishing; 1988.

- International Union for Conservation of Nature (IUCN). Standards and Petitions Subcommittee. Guidelines for using the IUCN Red List categories and criteria. Version 14 [Internet]. 2019[accessed September 2019]. Available from: http://www.iucnredlist.org/documents/ RedListGuidelines.pdf

- Jégu M. Subfamily Serrasalminae (Pacus and piranhas). In: Reis RE, Kullander SO, Ferraris Jr. CJ, editors. Check list of the freshwater fishes of South and Central America. Porto Alegre: Edipucrs; 2003. p.182-96.

- Jégu M, Hubert N, Belmont-Jégu E. Réhabilitation de Myloplus asterias (Müller \& Troschel, 1844), espèce-type de Myloplus Gill, 1896 et validation du genre Myloplus Gill (Characidae: Serrasalminae). Cybium. 2004; 28(2):119-57.
- Jégu M, Keith P, Le Bail PY. Myloplus planquettei sp. n. (Teleostei, Characidae), une nouvelle espèce de grand Serrasalminae phytophage du bouclier guyanais. Rev Suisse Zool. 2003; 110:83353. https://doi.org/10.5962/bhl.part.80216

- Kapli P, Lutteropp S, Zhang J, Kobert K, Pavlidis P, Stamatakis A, Flouri T. Multirate Poisson tree processes for single-locus species delimitation under maximum likelihood and Markov chain Monte Carlo. Bioinformatics. 2017; 33(11):1630-38. https://doi.org/10.1093/bioinformatics/ btx025

- Katoh K, Standley DM. MAFFT multiple sequence alignment software version 7: improvements in performance and usability. Mol Biol Evol. 2013; 30(4):772-80. https://doi.org/10.1093/molbev/mst010

- Lima FCT, Ribeiro AC. Continental-scale tectonic controls of biogeography and ecology. In: Albert JS, Reis RE, editors. Historical biogeography of Neotropical freshwater fishes. Los Angeles: University of California Press; 2011. p.145-64.

- Machado VN, Collins RA, Ota RP, Andrade MC, Farias IP, Hrbek T. One thousand DNA barcodes of piranhas and pacus reveal geographic structure and unrecognised diversity in the Amazon. Sci Rep. 2018; 8:8387. https://doi.org/10.1038/ s41598-018-26550-x

- Mattox GMT, Britz R, Toledo-Piza M. Skeletal development and ossification sequence of the characiform Salminus brasiliensis (Ostariophysi: Characidae). Ichthyol Explor Freshw. 2014; 25(2):103-58.

- Melo BF, Vari RP, Oliveira C. Curimatopsis maculosa, a new species from the rio Tapajós, Amazon basin, Brazil (Teleostei: Curimatidae). Ichthyol Explor Freshw. 2016; 27(4):303-08.

- Morales BF, Ota RP, Silva VDP, Deus CP. Ichthyofauna from floodplain lakes of Reserva de Desenvolvimento Sustentável Piagaçu-Purus (RDS-PP), lower rio Purus. Biota Neotrop. 19(4):e20190779. http:// dx.doi.org/10.1590/1676-0611-BN-2019-0779

- Nico LG, Jégu M, Andrade MC. Family Serrasalmidae - Piranhas and Pacus. In: van der Sleen P, Albert JS, organizers. Field guide to the fishes of the Amazon, Orinoco, and Guianas (Princeton Field Guides). 1ed. Princeton: Princeton University Press; 2018. p.172-96. 
- Ota RP, Py-Daniel LHR, Jégu M. A new Silver Dollar species of Metynnis Cope, 1878 (Characiformes: Serrasalmidae) from northwestern Brazil and southern Venezuela. Neotrop Ichthyol. 2016; 14(4):e160023. https://doi.org/10.1590/19820224-20160023

- Padial JM, Miralles A, De la Riva I, Vences $M$. The integrative future of taxonomy. Front Zool. 2010; 7(16):1-14. https://doi.org/10.1186/1742-9994-7-16

- Rambaut A, Drummond AJ, Xie D, Baele G, Suchard MA. Posterior summarization in Bayesian phylogenetics using Tracer 1.7. Syst Biol. 2018; 67(5):901-04. https://doi. org/10.1093/sysbio/syy032

- Reid NM, Carstens BC. Phylogenetic estimation error can decrease the accuracy of species delimitation: a Bayesian implementation of the general mixed Yulecoalescent model. BMC Evol Biol. 2012; 12:196(2012). https://doi.org/10.1186/14712148-12-196

- Roberts TR. Ecology of fishes in the Amazon and Congo Basins. Bull Mus Comp Zool. 1972; 143:117-47.

- Ruokolainen K, Moulatlet GM, Zuquim G, Hoorn C, Tuomisto H. River network rearrangements in Amazonia shake biogeography and civil security. Preprints; 2018. https://doi.org/10.20944/ preprints201809.0168.v1

- Ruokolainen K, Moulatlet GM, Zuquim G, Hoorn C, Tuomisto H. Geologically recent rearrangements in central Amazonian river network and their importance for the riverine barrier hypothesis. Front Biogeogr. 2019; 11(3):119. https://doi.org/10.21425/F5FBG45046

- Sambrook J, Russell DW. Molecular cloning: a laboratory manual. New York, Cold Spring Harbor Press. Cold Spring Harbor, v. I.; 2001.
- Saint-Paul U, Zuanon JA, Villacorta Correa MA, Garcia M, Fabré NN, Berger U, Junk WJ. Fish communities in central Amazonian white- and blackwater floodplains. Environ Biol Fishes. 2000; 57(3):235-50. https://doi. org/10.1023/A:1007699130333

- Schliep KP. Phangorn: phylogenetic analysis in R. Bioinformatics. 2010; 27(4):592-93. https://doi.org/10.1093/ bioinformatics/btq706

- Sioli H. The Amazon: limnology and landscape ecology of a mighty tropical river and its basin. Dordrecht: Dr. W. Junk Publishers; Monographiae Biologicae, v. 56; 1984

- Suchard MA, Lemey P, Baele G, Ayres DL, Drummond AJ, Rambaut A. Bayesian phylogenetic and phylodynamic data integration using BEAST 1.10. Virus Evol. 2018; 4(1):1-5. http://dx.doi.org/10.1093/ve/ vey016

- Thompson AW, Betancur-RR, LópezFernández H, Ortí G. A time-calibrated, multi-locus phylogeny of piranhas and pacus (Characiformes: Serrasalmidae) and a comparison of species tree methods. Mol Phylogenet Evol. 2014; 81:242-57. http:// dx.doi.org/10.1016/j.ympev.2014.06.018

- Vazzoler AEAM. Biologia da reprodução de peixes Teleósteos: teoria e prática. Maringá: Editora Universidade Estadual de Maringá, Maringá; 1996.

- Wallace AR. A narrative of travels on the Amazon and Rio Negro: with an account of the native tribes, and observations on the climate, geology, and natural history of the Amazon valley. London, New York, Melbourne: Ward, Lock, Minerva Library of Famous Books; 1889.

- Zeinad AK, Prado RA. Peixes fluviais do Brasil: espécies esportivas. Campinas: Pescaventura; 2012.

\section{AUTHOR CONTRIBUTIONS}

Rafaela Priscila Ota: Conceptualization, Data curation, Formal Analysis, Methodology, Software, Supervision, Validation, Visualization, Writing (original draft), Writing (review \& editing).

Valéria Nogueira Machado: Conceptualization, Data curation, Formal Analysis, Investigation,

Methodology, Software, Supervision, Validation, Writing (review \& editing).

Marcelo C. Andrade: Conceptualization, Data curation, Investigation, Methodology, Validation, Writing (original draft), Writing (review \& editing).

Rupert A. Collins: Conceptualization, Data curation, Formal Analysis, Investigation, Methodology, Software, Validation, Visualization, Writing (original draft), Writing (review \& editing). 


\section{Neotropical Ichthyology}

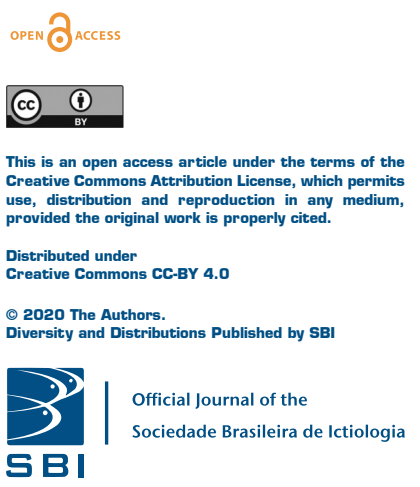

Izeni Pires Farias: Funding acquisition, Project administration, Resources, Supervision, Validation, Writing (review \& editing).

Tomas Hrbek: Formal Analysis, Investigation, Methodology, Resources, Supervision, Writing (original draft), Writing (review \& editing).

\section{ETHICAL STATEMENTS}

The material was collected under the permanent licenses of Izeni Pires Farias (11325-1) and Lucia Helena Rapp Py-Daniel (11561-1).

\section{COMPETING INTERESTS}

The authors declare no competing interests.

\section{HOW TO CITE THIS ARTICLE}

- Ota RP, Machado VN, Andrade MC, Collins RA, Farias IP, Hrbek T. Integrative taxonomy reveals a new species of pacu (Characiformes: Serrasalmidae: Myloplus) from the Brazilian Amazon. Neotrop Ichthyol. 2020; 18(1):e190112. https://doi.org/10.1590/1982-0224-20190112 